ARTICLE

https://doi.org/10.1038/s41467-020-15812-w

\title{
Cable bacteria reduce methane emissions from rice-vegetated soils
}

Vincent V. Scholz (10 ${ }^{1 凶}$, Rainer U. Meckenstock ${ }^{2}$, Lars Peter Nielsen (10 ${ }^{1}$ \& Nils Risgaard-Petersen ${ }^{1}$

Methane is the second most important greenhouse gas after carbon dioxide and approximately $11 \%$ of the global anthropogenic methane emissions originate from rice fields. Sulfate amendment is a mitigation strategy to reduce methane emissions from rice fields because sulfate reducers and methanogens compete for the same substrates. Cable bacteria are filamentous bacteria known to increase sulfate levels via electrogenic sulfide oxidation. Here we show that one-time inoculation of rice-vegetated soil pots with cable bacteria increases the sulfate inventory 5 -fold, which leads to the reduction of methane emissions by $93 \%$, compared to control pots lacking cable bacteria. Promoting cable bacteria in rice fields by enrichment or sensible management may thus become a strategy to reduce anthropogenic methane emissions.

\footnotetext{
${ }^{1}$ Center for Electromicrobiology, Aarhus University, 8000 Aarhus C, Denmark. ${ }^{2}$ Environmental Microbiology and Biotechnology, University Duisburg-Essen,

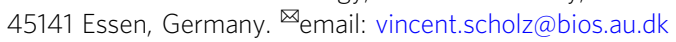


C able bacteria are filamentous bacteria of the family Desulfobulbaceae ${ }^{1}$, which spatially decouple the oxidation of sulfide and the reduction of oxygen ${ }^{2}$ or nitrate ${ }^{3}$ in marine ${ }^{4,5}$ and freshwater systems $s^{6,7}$ by channeling electrons along their filaments. This process is called electrogenic sulfide oxidation (e-SOX) and results in the centimeters-wide depletion of sulfide and accumulation of the end-product sulfate ${ }^{8-10}$. The sulfate inventory is further fueled by the dissolution of iron sulfides through the release of protons from e-SOX and the subsequent oxidation of the liberated sulfides to sulfate ${ }^{10,11}$. Moreover, the establishment of an electric field through e-SOX causes downward migration of sulfate and minimizes its loss to the water column ${ }^{6}$. Hence, the electric field contributes to the eSOX-driven accumulation of sulfate, which has recently been shown to stimulate sulfate reduction ${ }^{12}$.

External amendment of sulfate-containing compounds such as ammonium sulfate or gypsum to wetland rice soils is known to mitigate methane $\left(\mathrm{CH}_{4}\right)$ emissions ${ }^{13}$. This is because additions of sulfate stimulate sulfate reduction in otherwise sulfate-limited environments, which leads to substrate limitation of methanogenesis, as sulfate-reducing microorganisms are superior to methanogens as competitors for common substrates such as hydrogen and acetate ${ }^{14,15}$.

However, the externally amended sulfate can be quickly converted to sulfide, which tend to accumulate in the soil, implying that prolonged effects on $\mathrm{CH}_{4}$ emissions can only be achieved by re-application of low amounts of sulfate ${ }^{16,17}$. Here, we carried out rice pot experiments with autoclaved wetland soil which was mixed with cow dung to inoculate a complex microbial community lacking cable bacteria. Half of the pots were then inoculated with the freshwater cable bacteria $\mathrm{Ca}$. Electronema sp. GS ${ }^{9}$. After 11 weeks of incubation under water saturation, sulfate concentrations, $\mathrm{CH}_{4}$ emissions, and cable bacteria abundance and activity were determined. Our results indicate that cable bacteria reduce $\mathrm{CH}_{4}$ emissions from rice-vegetated soils by recycling sulfate via e-SOX.

\section{Results}

Cable bacteria distribution. After the 11-week incubation period, no difference of the above-ground biomass of the rice plants between the treatments was observed $(P=0.64, n=8$, unpaired two-tailed $t$-test, see Supplementary Fig. 1). Fluorescence in situ hybridization (FISH) showed $400 \pm 100 \mathrm{~m} \mathrm{~cm}^{-2}$ cable bacteria filaments in the inoculated pots, demonstrating that the cable bacteria could be successfully transferred to cable bacteria-free soils and grew to high densities. Most of the cable bacterial cells were located in the uppermost $2 \mathrm{~cm}$ (Fig. 1a, Supplementary Fig. 2a). Moreover, cable bacteria were found in close contact with the rice roots (Fig. 1b, Supplementary Fig. 2b). Nevertheless, the observed higher filament density in the upper soil layers indicated that most of the cable bacteria reduced oxygen diffusing from the water column into the soil. No cable bacteria filaments were seen in the control rice pots after the 11-week incubation period.

Sulfate and $\mathbf{p H}$ depth profiles. The sulfate concentration in the overlaying water phase of the cable bacteria-free and cable bacteria incubation was $1646 \pm 3$ and $2230 \pm 20 \mu \mathrm{M}(n=3$, technical replicates), respectively. Without cable bacteria, the sulfate concentration of the soil porewater declined from $1000 \pm 100$ to $70 \pm$ $20 \mu \mathrm{M}$ in $4 \mathrm{~cm}$ depth, indicating that the sulfate diffusing from the water column into the soil was reduced with no reformation by sulfide oxidation in deeper soil layers (Fig. 2a). With cable bacteria, the sulfate inventory of the soil porewater in the upper $4 \mathrm{~cm}\left(90 \pm 20 \mathrm{mmol}\right.$ sulfate $\left.\mathrm{m}^{-2}\right)$ was five times higher $(P=$ $0.006, n=8$, unpaired two-tailed $t$-test) than in pots without cable bacteria $\left(17 \pm 2 \mathrm{mmol}\right.$ sulfate $\left.\mathrm{m}^{-2}\right)$ and the sulfate concentration was uniform throughout the first $4 \mathrm{~cm}$ of the soil, ranging from $1900 \pm 100 \mu \mathrm{M}$ in the top centimeter to $2200 \pm$ $700 \mu \mathrm{M}$ at $3-4 \mathrm{~cm}$ depth (Fig. 2a). The experimental design did not allow to retrieve soil samples from the lower $3 \mathrm{~cm}$ of the pots, but the facts that the sulfate concentrations in the $3-4 \mathrm{~cm}$ depth section of the pots with cable bacteria were about twice as high as the concentrations in the top centimeter of pots without cable bacteria and sulfate yet penetrated $4 \mathrm{~cm}$ in the latter do imply that sulfate penetrated to the bottom of the cable bacteria pots, assuming similar potential sulfate reduction rates.

Furthermore, typical effects of e-SOX ${ }^{6,10}$ in the cable bacteriaamended pots developed during the incubation period. The $\mathrm{pH}$ decreased by 0.24 units in $7.2 \mathrm{~mm}$ depth (Fig. 2b) and an orange layer formed on top of the soil surface (Supplementary Fig. 1), which probably originates from dissolution of iron sulfides and subsequent diffusion, oxidation, and precipitation of iron as ferric iron oxides ${ }^{18}$. The sulfide from dissolution of iron sulfide gets oxidized to sulfate by e-SOX and most likely contributed to the overall sulfate inventory in pots with cable bacteria.

$\mathrm{CH}_{4}$ emission. $\mathrm{CH}_{4}$ emission rates from the pots were calculated from the linear increase of $\mathrm{CH}_{4}$ in the incubation system (Fig. 3). The $\mathrm{CH}_{4}$ emission from the pots with cable bacteria was significantly $(P=0.006, n=8$, unpaired two-tailed $t$-test) lower than the emission from the pots without cable bacteria ( $42 \pm 9$ vs. $\left.\left.600 \pm 100 \mu \mathrm{mol} \mathrm{m}^{-2} \mathrm{day}^{-1}\right)\right)$. Thus, presence of cable bacteria led to a reduction of $\mathrm{CH}_{4}$ emissions by $93 \%$.

\section{Discussion}

The cable bacteria-mediated $93 \%$ reduction of $\mathrm{CH}_{4}$ emission is one of the highest reported reduction efficiencies compared to studies where sulfate was added ${ }^{13,16,17}$. The main controlling

a
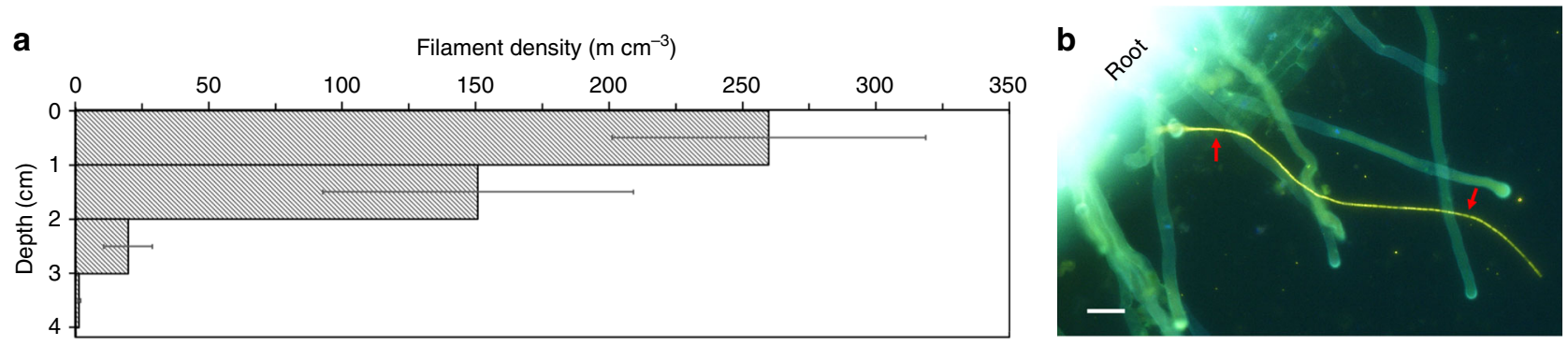

Fig. 1 Distribution of cable bacteria in rice-vegetated pots. a Depth profile of the cable bacteria filament densities in inoculated rice soils. Data are presented as mean \pm standard error of the mean $(n=4)$. b Micrograph of a cable bacteria filament in close contact with a rice root. Image from DAPI staining (blue) was superimposed with FISH images hybridized with probe DSB706 specific for Desulfobulbaceae labeled with Cy3 (red) and probe EUBMIX targeting most bacteria labeled with Atto-488 (green). Red arrows point to the cable bacteria filament. Scale bar, $20 \mu \mathrm{m}$. 
a

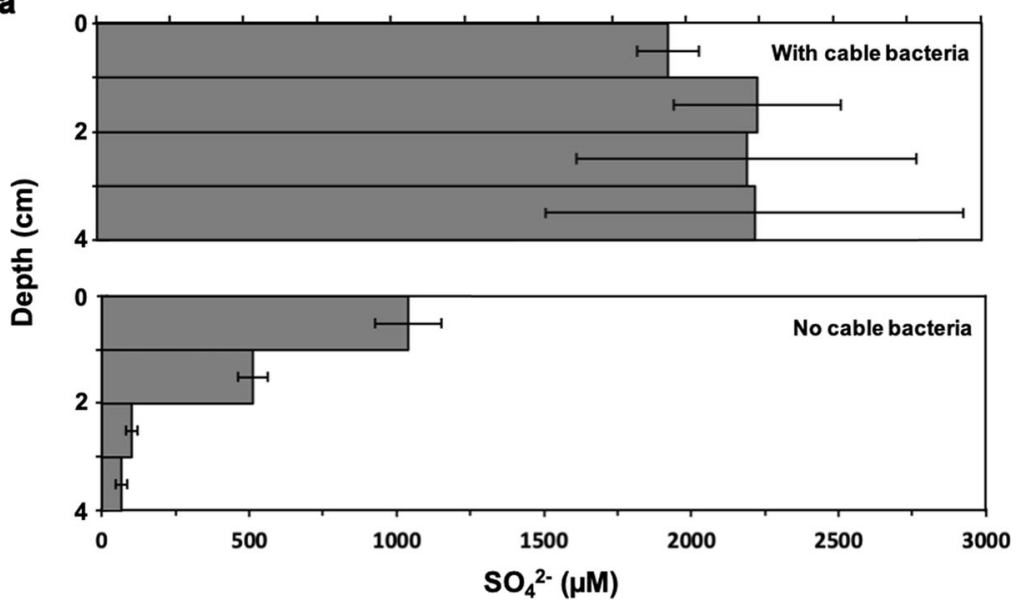

b

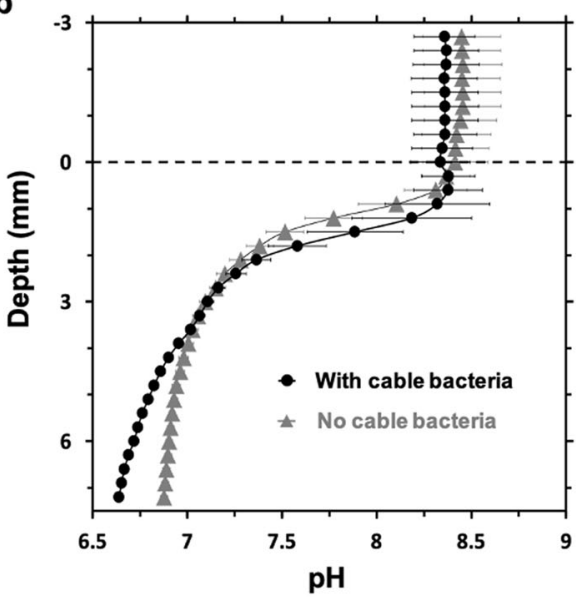

Fig. 2 Sulfate concentrations and pH in the rice-vegetated pots. a Sulfate concentrations in the porewater of pots with cable bacteria (top) and in pots without cable bacteria (bottom). b Depth profiles of pH measured with microelectrodes in pots with cable bacteria (circles) and without cable bacteria (triangles). Data are presented as mean \pm standard error of the mean $(n=4)$.

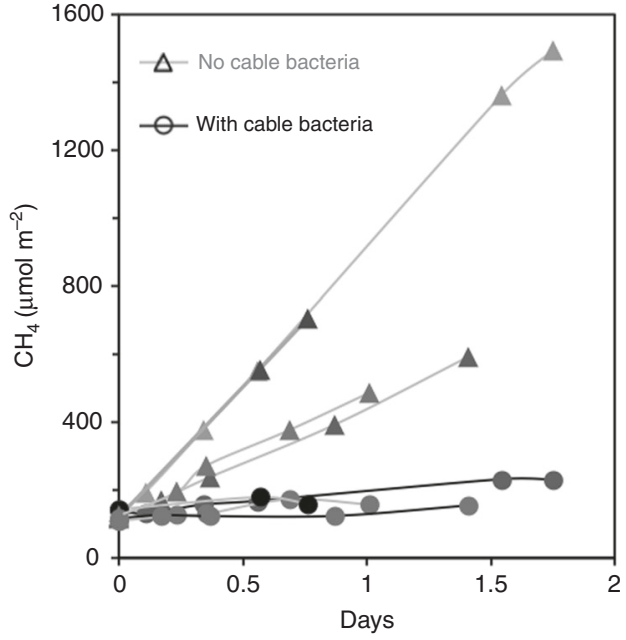

Fig. $3 \mathbf{C H}_{\mathbf{4}}$ emissions. The emitted amount of $\mathrm{CH}_{4}$ from replicate rice pots with cable bacteria (circles) and without cable bacteria (triangles) normalized to the surface area of the pots as a function of time.

factor in our experiments was likely the sulfate accumulation which was uniformly distributed in the upper $4 \mathrm{~cm}$ in pots with cable bacteria, suggesting that sulfate reduction was balanced by sulfur re-oxidation via e-SOX and eventually that ionic migration adds to the transport of sulfate ${ }^{12}$. The sulfate accumulation stimulated the activity of sulfate-reducing bacteria and therefore outcompeted methanogens for common substrates such as hydrogen or acetate. These substrates were supplied from fermentations processes, which were fueled by organic carbon from root exudations and sloughed root material ${ }^{19}$. Moreover, we chose autoclaved wetland soil as universal matrix to test our hypothesis. This wetland soil was supplemented with cow dung to provide an inoculum consisting of a complex microbial community including fermenters, methanogens, and sulfate-reducing bacteria ${ }^{20}$ but no cable bacteria, which also increased the organic carbon pool in the incubation pots at the beginning of our experiment. Beyond augmenting sulfate, e-SOX produced acidity. Microprofiles of $\mathrm{pH}$ were only taken down to $7.2 \mathrm{~mm}$ depth to minimize the risk of sensor collision with the roots which would break the sensor. However, it has been shown previously that eSOX produces acidity even down to $4 \mathrm{~cm}^{12}$. Low $\mathrm{pH}$ values

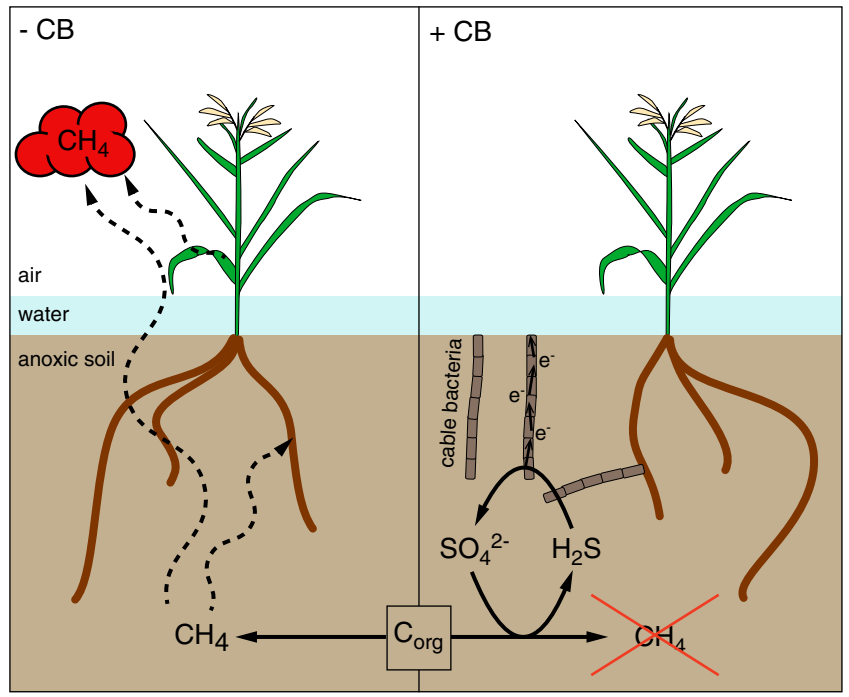

Fig. 4 Potential microbial-mediated processes. In rice-vegetated soils without cable bacteria (left) and with cable bacteria (right) organic carbon $\left(C_{\text {org }}\right)$, e.g. from root exudation, is degraded by a consortium of microorganisms to acetate and hydrogen, which are the main substrates for methanogens. In soils with cable bacteria, increased sulfate concentrations due to e-SOX stimulate sulfate-reducing bacteria, which outcompete methanogens for common substrates. The produced $\mathrm{CH}_{4}$ can enter to the atmosphere through the soil and the plants (dotted arrows).

impede fermentation processes and methanogenesis, resulting in the reduction of methane emissions ${ }^{21,22}$. For example, a $\mathrm{pH}$ shift from $\mathrm{pH} 6.9$ to 6.8 has been reported to decrease $\mathrm{CH}_{4}$ production in flooded rice soil by $26 \%{ }^{23}$. Taken together, the multifarious effects of e-SOX, i.e. sulfate accumulation and $\mathrm{pH}$ decrease, may explain the strong impact on $\mathrm{CH}_{4}$ emissions (Fig. 4).

In contrast to sulfate amendments as mitigation strategy where the effect on $\mathrm{CH}_{4}$ emissions weakens after the application ${ }^{17}$, the cable bacteria-mediated sulfate accumulation was actively maintained through e-SOX even after 11 weeks incubation. Furthermore, external amendments of sulfate may result in the build-up of toxic sulfide concentrations ${ }^{17,24}$ whereas e-SOX prevents such build-up ${ }^{2,6,10}$ and possibly even promotes the plant performance through provision of sulfate as nutrient ${ }^{25}$. 
Cable bacteria successfully established after one-time inoculation and the filament density was well within the typical range of cable bacteria abundance ${ }^{6,26}$. Cable bacteria were also found on roots which is congruent with previous studies that report the enrichment of cable bacteria on oxygen-releasing plant roots ${ }^{27,28}$. Indeed, rice roots can release oxygen ${ }^{29}$ providing the electron acceptor for cable bacteria. Thus, wetland rice fields might constitute an ideal habitat for cable bacteria. Our finding arises the questions to what extent cable bacteria grow in wetland rice fields and whether their presence can be promoted by the one-time inoculation with cable bacteria at the beginning of the rice cultivation period and through adjusted water levels to keep the top soil layer well oxygenated throughout the cultivation period.

\section{Methods}

Plant growth. Seedlings of Oryza sativa were germinated in tap water and grown to the three-leaf stage in commercially purchased garden soil under drained conditions. Wetland soil was retrieved from a small eutrophic lake in Aarhus, Denmark $\left(56^{\circ} 09^{\prime} 53.32 \mathrm{~N}, 10^{\circ} 12^{\prime} 28.73 \mathrm{E}\right)$ in April 2019 , sieved, and autoclaved. Freshly collected cow dung was mixed with the autoclaved soil. The soil was then inoculated with cable bacteria by adding cable bacteria enrichment culture of $\mathrm{Ca}$ Electronema sp. GS $S^{9}$ to the soil-cow dung mixture $(\approx 1500: 1, \mathrm{v} / \mathrm{v})$. After carefully homogenizing the soil and filling into growth pots (depth: $7 \mathrm{~cm}$; diameter: $12 \mathrm{~cm}$ ), the first $2 \mathrm{~cm}$ of the soil in each pot were further inoculated with the cable bacteria enrichment culture $(\approx 225: 1, \mathrm{v} / \mathrm{v})$ and carefully homogenized. After transplanting the rice plants, the four replicates of each treatment were placed into incubation tanks with aerated tap water. Cross-contamination was excluded by avoiding direct contact between the two incubation tanks. The water level was continuously kept above the soil surface up to several centimeters. The plants were grown at room temperature and at the window under natural light conditions for 11 weeks with additional illumination in the first weeks. After sampling, the above-ground biomass from each rice plant was collected and dried at $80{ }^{\circ} \mathrm{C}$ for $44 \mathrm{~h}$ to determine the dry weight.

Microelectrode measurements. After the 11-week incubation period, depth profiles of $\mathrm{pH}$ were recorded with custom-made microsensors ${ }^{30}$ and a commercially available reference electrode (Red Rod reference electrode, REF201, Radiometer Analytical, Denmark). The software SensorTrace Pro (Unisense A/S, Denmark) was used to operate the micromanipulator and for data acquisition. The $\mathrm{pH}$ sensors were calibrated in buffers of $\mathrm{pH} 4,7$, and 10 (HANNA instruments, UK) and the depth of each profile was corrected in MS Excel (Microsoft Corporation, United States)

$\mathbf{C H}_{\mathbf{4}}$ measurement. Following the microelectrode measurements, the pots were taken out of the water tank and any remaining water on top of the soil was carefully removed. Pots were placed into a custom-made opaque PVC chamber (inner dimensions: $91 \mathrm{~cm}$ height, $14 \mathrm{~cm}$ diameter) with a rubber septum at the top and incubated up to 2.5 days. Headspace samples of $500 \mu \mathrm{L}$ were withdrawn with a syringe and directly injected into a gas chromatograph (310 C, SRI Instruments, United States) equipped with a flame ionization detector.

Sulfate and FISH analysis. One soil core with an inner diameter of $4.5 \mathrm{~cm}$ from each pot was taken and sliced into four sections of $1 \mathrm{~cm}$ width. For sulfate measurement, the porewater from each depth section was separated from the solid phase by centrifugation, filtered through $0.22 \mu \mathrm{m}$, and stored at $6^{\circ} \mathrm{C}$ until analysis by ion chromatography (Dionex, USA) with a AG18 Guard column and Dionex IonPac AS18 column (Thermo Fisher Scientific, USA). The run time was $18 \mathrm{~min}$ with sulfate eluting at $9.5 \mathrm{~min}$.

For FISH analysis, $0.5 \mathrm{~mL}$ soil from each section was mixed with $0.5 \mathrm{~mL}$ ethanol and stored at $-20^{\circ} \mathrm{C}$. After taking the core, roots sections were cut out of the remaining soil with scissors, stored, and washed in $50 \%$ ethanol, and dried and embedded in $0.5 \%$ agarose on a well-slide. Cable bacteria filaments were stained and quantified by FISH as described earlier ${ }^{27}$.

Statistical analysis. Results are displayed as mean \pm s.e.m. of four biological replicates unless stated differently in the text. The dry weight of the above-ground biomass, $\mathrm{CH}_{4}$ emissions rates, and depth integrated sulfate concentrations were tested for difference between rice pots with and without cable bacteria using the unpaired two-tailed Student's $t$-test with the significance level of 0.05 , eight observations and six degrees of freedom.

The experimental design is illustrated in Supplementary Fig. 3.

Reporting summary. Further information on research design is available in the Nature Research Reporting Summary linked to this article.

\section{Data availability}

The raw data generated in this study are available from the corresponding author upon request.

Received: 25 December 2019; Accepted: 30 March 2020;

Published online: 20 April 2020

\section{References}

1. Pfeffer, C. et al. Filamentous bacteria transport electrons over centimetre distances. Nature 491, 218 (2012).

2. Nielsen, L. P., Risgaard-Petersen, N., Fossing, H., Christensen, P. B. \& Sayama M. Electric currents couple spatially separated biogeochemical processes in marine sediment. Nature 463, 1071-1074 (2010).

3. Marzocchi, U. et al. Electric coupling between distant nitrate reduction and sulfide oxidation in marine sediment. ISME J. 8, 1682 (2014).

4. Burdorf, L. D. W. et al. Long-distance electron transport occurs globally in marine sediments. Biogeosciences 14, 683-701 (2017).

5. Malkin, S. Y. et al. Natural occurrence of microbial sulphur oxidation by longrange electron transport in the seafloor. ISME J. 8, 1843-1854 (2014).

6. Risgaard-Petersen, N. et al. Cable bacteria in freshwater sediments. Appl. Environ. Microbiol. 81, 6003-6011 (2015).

7. Müller, H. et al. Long-distance electron transfer by cable bacteria in aquifer sediments. ISME J. 10, 2010-2019 (2016).

8. Müller, H., Marozava, S., Probst, A. J. \& Meckenstock, R. U. Groundwater cable bacteria conserve energy by sulfur disproportionation. ISME J. 14, 623-634 (2020).

9. Kjeldsen, K. U. et al. On the evolution and physiology of cable bacteria. Proc Natl. Acad. Sci. USA 116, 19116-19125 (2019).

10. Risgaard-Petersen, N., Revil, A., Meister, P. \& Nielsen, L. P. Sulfur, iron-, and calcium cycling associated with natural electric currents running through marine sediment. Geochim. Cosmochim. Acta 92, 1-13 (2012).

11. Rao, A. M., Malkin, S. Y., Hidalgo-Martinez, S. \& Meysman, F. J. The impact of electrogenic sulfide oxidation on elemental cycling and solute fluxes in coastal sediment. Geochim. Cosmochim. Acta 172, 265-286 (2016).

12. Sandfeld, T., Marzocchi, U., Petro, C., Schramm, A. \& Risgaard-Petersen, N Electrogenic sulfide oxidation mediated by cable bacteria stimulates sulfate reduction in freshwater sediments. ISME J. https://doi.org/10.1038/s41396020-0607-5 (2020).

13. van der Gon, H. A. D., van Bodegom, P. M., Wassmann, R., Lantin, R. S. \& Metra-Corton, T. M. Sulfate-containing amendments to reduce methane emissions from rice fields: mechanisms, effectiveness and costs. Mitig. Adapt. Strat. Glob. Change 6, 71-89 (2001).

14. Kristjansson, J. K., Schönheit, P. \& Thauer, R. K. Different Ks values for hydrogen of methanogenic bacteria and sulfate reducing bacteria: an explanation for the apparent inhibition of methanogenesis by sulfate. Arch. Microbiol. 131, 278-282 (1982).

15. Schönheit, P., Kristjansson, J. K. \& Thauer, R. K. Kinetic mechanism for the ability of sulfate reducers to out-compete methanogens for acetate. Arch. Microbiol. 132, 285-288 (1982).

16. Wörner, S. et al. Gypsum amendment to rice paddy soil stimulated bacteria involved in sulfur cycling but largely preserved the phylogenetic composition of the total bacterial community. Environ. Microbiol. Rep. 8, 413-423 (2016).

17. Saenjan, P., Ro, S. \& Vityakon, P. Methane fluxes and rice yields as a function of sulfate fertilizer with incorporated rice stubble. Asia Pac. J. Sci. Technol. 20 337-345 (2015).

18. Seitaj, D. et al. Cable bacteria generate a firewall against euxinia in seasonally hypoxic basins. Proc. Natl. Acad. Sci. USA 112, 13278-13283 (2015).

19. Lu, Y., Wassmann, R., Neue, H.-U. \& Huang, C. Dynamics of dissolved organic carbon and methane emissions in a flooded rice soil. Soil Sci. Soc. Am. J. 64, 2011-2017 (2000).

20. Cummings, B., Caldwell, D., Gould, D. \& Hamar, D. Identity and interactions of rumen microbes associated with dietary sulfate-induced polioencephalomalacia in cattle. Am. J. Vet. Res. 56, 1384-1389 (1995).

21. Habtewold, J. et al. Reduction in methane emissions from acidified dairy slurry is related to inhibition of Methanosarcina species. Front. Microbiol. 9, 2806 (2018).

22. Ye, R. et al. pH controls over anaerobic carbon mineralization, the efficiency of methane production, and methanogenic pathways in peatlands across an ombrotrophic-minerotrophic gradient. Soil Biol. Biochem. 54, 36-47 (2012).

23. Wang, Z. P., DeLaune, R. D., Patrick, W. H. \& Masscheleyn, P. H. Soil redox and $\mathrm{pH}$ effects on methane production in a flooded rice soil. Soil Sci. Soc. Am. J. 57, 382-385 (1993). 
24. Myrbo, A. et al. Sulfide generated by sulfate reduction is a primary controller of the occurrence of wild rice (Zizania palustris) in shallow aquatic ecosystems. J. Geophys. Res. Biogeosci. 122, 2736-2753 (2017).

25. Williams, J. F., Mutters, R. G. \& Greer, C. A. Rice Nutrient Management in California (UCANR Publ., Publ. 3516, Oakland, CA, 2010).

26. Schauer, R. et al. Succession of cable bacteria and electric currents in marine sediment. ISME J. 8, 1314-1322 (2014)

27. Scholz, V. V., Müller, H., Koren, K., Nielsen, L. P. \& Meckenstock, R. U. The rhizosphere of aquatic plants is a habitat for cable bacteria. FEMS Microbiol. Ecol. 95, fiz062 (2019).

28. Martin, B. C. et al. Oxygen loss from seagrass roots coincides with colonisation of sulphide-oxidising cable bacteria and reduces sulphide stress. ISME J. 13, 707-719 (2018).

29. Larsen, M. et al. O2 dynamics in the rhizosphere of young rice plants (Oryza sativa L.) as studied by planar optodes. Plant Soil 390, 279-292 (2015).

30. Revsbech, N. P. \& Jørgensen, B. B. in Advances in Microbial Ecology, Vol. 9, 293-352 (Springer, Boston, 1986).

\section{Acknowledgements}

We acknowledge Ronny Mario Baaske, Mette L.G. Nikolajsen, and Theresa Merl for assistance in rice cultivation; Lars Borregaard Pedersen for making the microsensors; and Karina Bomholt Oest for help with the sulfate measurements. Casper Thorup and Ronny Mario Baaske are thanked for providing sediment enrichments of $\mathrm{Ca}$. Electronema sp. GS. Korneel Rabaey is thanked for help in conceiving the hypothesis. This research was financially supported by the Danish National Research Foundation DNRF136.

\section{Author contributions}

V.V.S. designed and carried out the experiment and wrote the manuscript with input from all the co-authors. R.U.M. conceived the idea of the project and contributed to the design of the experiment. L.P.N. helped with interpretations of the results. N.R.-P. guided the research and assisted with data analysis.

\section{Competing interests}

The authors declare no competing interests.

\section{Additional information}

Supplementary information is available for this paper at https://doi.org/10.1038/s41467020-15812-w.

Correspondence and requests for materials should be addressed to V.V.S.

Peer review information: Nature Communication thanks Sairah Malkin and the other, anonymous, reviewer(s) for their contribution to the peer review of this work. Peer review reports are available.

Reprints and permission information is available at http://www.nature.com/reprints

Publisher's note Springer Nature remains neutral with regard to jurisdictional claims in published maps and institutional affiliations.

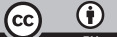

Open Access This article is licensed under a Creative Commons Attribution 4.0 International License, which permits use, sharing, adaptation, distribution and reproduction in any medium or format, as long as you give appropriate credit to the original author(s) and the source, provide a link to the Creative Commons license, and indicate if changes were made. The images or other third party material in this article are included in the article's Creative Commons license, unless indicated otherwise in a credit line to the material. If material is not included in the article's Creative Commons license and your intended use is not permitted by statutory regulation or exceeds the permitted use, you will need to obtain permission directly from the copyright holder. To view a copy of this license, visit http://creativecommons.org/ licenses/by/4.0/.

(c) The Author(s) 2020, corrected publication 2022 